\title{
Volatile Organic Compounds as Novel Markers for the Detection of Bacterial Infections
}

\author{
Mohsen Sohrabi ${ }^{1}$, Li Zhang ${ }^{2 *}$, Kai Zhang ${ }^{1}$, Adnan Ahmetagic ${ }^{1}$ and Ming Q Wei ${ }^{1}$ \\ ${ }^{1}$ Division of Molecular and Gene Therapies, Griffith Health Institute and School of Medical Science, Griffith University, Gold Coast, Australia \\ ${ }^{2}$ Centre for Health Practice Innovation and Griffith Health Institute, Griffith University, Nathan, Australia
}

*Corresponding author: Li Zhang, Centre for Health Practice Innovation and Griffith Health Institute, Griffith University, Nathan, QLD 4111, Australia, Tel: +61 (0)7 3735 7272; E-mail: li.zhang@griffith.edu.au

Rec date: Apr 17, 2014; Acc date: May 20, 2014; Pub date: May 28, 2014

Copyright: @ 2014 Sohrabi M, et al. This is an open-access article distributed under the terms of the Creative Commons Attribution License, which permits unrestricted use, distribution, and reproduction in any medium, provided the original author and source are credited.

\begin{abstract}
Bacterial volatile organic compounds (VOCs) have been considered as sensitive and specific biomarkers for bacterial detection in human specimens and culture media. The possibility of using VOCs markers as one of the largest groups of bacterial metabolites would open a new frontier for developing more efficient techniques in the diagnosis of bacterial infections. This review will discuss the current published theory and data regarding the use of bacterial VOCs as markers in bacterial infections.
\end{abstract}

Keywords: Volatile Organic Compounds (VOCs); Bacterial detection; Infectious diseases; Biomarker

\section{Introduction}

Many bacterial pathogens could lead to life-threatening infections. Accurate and rapid diagnosis is essential for the successful management of these infectious diseases. Traditional bacterial identification methods are time-consuming, require specific techniques and expertise. Other limitations of these techniques such as unaffordability and unavailability of expensive microbiological equipment and delay in the transport of human specimens such as fecal samples in diarrhea patients to the appropriate laboratories remain as main causes of delay in proceeding suitable curative actions in some countries. Therefore, all mentioned reasons have led to unavoidable delay in diagnosis and even death of infected patients [1].

Chemical analysis of bacterial culture includes analysis of bacterial metabolites, bacterial cell wall compositions and fatty acids profiling, have been introduced as bacterial differentiation and detection methods [2,3]. Metabolomics is a fast developing 'omics' that analyzes final metabolites of the cells by means of high throughput analytical technologies such as gas chromatography-mass spectrometry and high performance liquid chromatography-mass spectrometry [4]. Recent advances in ionization technologies allow researchers to perform sensitive qualitative and quantitative analysis of high molecular weight compounds along with the conventional ability of low molecular weight compound analysis in biological experiments [5]. This review will discuss the current published theory and data regarding the use of bacterial VOCs as markers in bacterial infections.

\section{Bacterial volatile organic compounds}

VOCs are carbon based molecules which are naturally volatile in ambient temperature with a minimum evaporate pressure of $1 \mathrm{kPa}$ $[6,7]$. These organic compounds are producing as parts of plants, humans, animals, mushrooms and microorganism's metabolic pathways. VOCs have been used for bacterial identification since 1964 when Geldreich and co-workers developed the Indole-Methyl redVoges-Proskauer and Citrate (IMVIC) test which was used for the detection of coliform based on the production of indole, acetoin, pyrovate and 2,3-butanediol in culture media [8]. Indole and 2aminoacetophenone are two examples of typical VOCs that have been used as common markers for Escherichia coli and Pseudomonas aeruginosa detection in culture media $[9,10]$. VOCs from bacterial pathogen have been used to develop sensitive and accurate methods to prove the absence or presence of pathogens as well as phenotyping within bacterial species. Such information could be used to take the best action regarding prevention or antibiotic treatment [11].

VOCs can be categorized in several groups including fatty acids, aromatic compounds, nitrogen containing compounds and sulfur volatile compounds [12]. Bacteria produce a wide range of VOCs as their primary or secondary metabolites in different physicochemical conditions. As it is summarized in Table 1, bacterial VOCs have been reported as significant bacterial differentiation and detection markers [1,13-21].

The VOCs profile of the bacterial communication depends on the diversity of the bacterial composition as well as available carbon and energy sources and physiochemical conditions in bacterial microenvironment [22]. For example, volatile short chain fatty acids (SCFAs) such as lactate, acetate, propionate and ethanol are produced via primary bacterial fermentation from carbohydrates. These SCFAs are in turn converted to VOCs such as butyrate, propionate, propanol etc. [22]. It is expected that increasing in the abundance of butyrate producing microorganism such as Bifidobacterium and Faecalibacterium would result in an increase in the level of butyrate concentration in VOCs analysis of human specimen which can be used as a quantitative marker for bacterial presence [23]. 


\begin{tabular}{|c|c|c|}
\hline Pathogens & Detected VOCs & Method \\
\hline \multirow{5}{*}{$P$. aeruginosa } & $\begin{array}{l}\text { Ethanol, Acetone, 2-Butanone, 2-Pentanone, Isoprene, Aminoacetophenone, Dimethyl sulphide, Dimethyl } \\
\text { disulphide, Dimethyl trisulphide, Methyl thiocyanate, 3-Methyl-butanone, Acetophenone, Methylthioacetate and } \\
\text { Methyl thiobutanoate, Hydrogen cyanide [13] }\end{array}$ & GC-MS $[13,15,17]$ \\
\hline & $\begin{array}{l}\text { Acetonitrile, Ethanol, Acetone, Acetic acid, Ethylene glycol, 2-Pentanone, 4-Methylphenol, Indole and 2- } \\
\text { Aminoacetophenone [14] }\end{array}$ & SIFT-MS $[13,16]$ \\
\hline & 2-Nonanone, 2-Undecanone, 2-Aminoacetophenone [15] & SESI-MS [14] \\
\hline & $\begin{array}{l}\text { Acetic acid, Acetone, Acetonitrile, Amonia, Butanone, DMS, DMDS, Ethanol, Hydrogen cyanide, Isoprene, } \\
\text { Methanol, Metanthiol [16] }\end{array}$ & \\
\hline & $\begin{array}{l}\text { Clinical samples: 2-Nonanone, 2,4-Dimethyl-1-heptene, 2-Nonanone, 2,4-Dimethyl-, 1-Heptene, 1-Butanol-3- } \\
\text { methyl, Limonene [17] }\end{array}$ & \\
\hline S. aureus & $\begin{array}{l}\text { Acetonitrile, Ethanol, Butanol, Acetone, Acetic acid, Ethylene glycol, Isopentanol, Pyrimidine, 2-Pentanone, 4- } \\
\text { Methylphenol, 2-Nonanone [14] }\end{array}$ & SESI-MS \\
\hline E. coli & Acetonitrile, Ethanol, Indole [14] & SESI-MS \\
\hline S. typhimurium & $\begin{array}{l}\text { Acetonitrile, Ethanol, Butanol, Acetone, Acetic acid, Ethylene glycol, Isopentanol, Pyrimidine, 2-Pentanone, 4- } \\
\text { Methylphenol, Indole, 2-Nonanone [14] }\end{array}$ & SESI-MS \\
\hline M. avium & $\begin{array}{l}\text { 2-Ethylfuran, 2-Methylfuran, 3-Methylfuran, Furan, 2-Pentylfuran, 2-Heptanone, 3-Octanone, Acetone, Methyl } \\
\text { Isobutyl Ketone, 2-Butanone, 3-Methyl-Butanal, 2-Methylpropanal, Methacrolein, 2-Ethylbutanal, 2-Methyl-2- } \\
\text { Butenal, Hexanal, 4-Methylheptane, 4-Methyloctane, 2,4-Dimethylheptane, Butane, Pentane, Hexane, Heptane, } \\
\text { Octane, 2,4-Dimethyl-1-Heptene, 2-Methyl-1-Pentene, Isoprene, Methylacetat, Ethylacetate, 2-Ethoxy-2- } \\
\text { Methylpropane, 1-Methyl-1-H-Pyrrole, 2-Methylbutanenitril, Dimethyldisulfide, Benzene [18] }\end{array}$ & GC-MS \\
\hline C. difficile & $\begin{array}{l}\text { Clinical samples: Acetic acid, Butanoic acid, 2-Furancarboxaldehyde, 5-Methyl-2-furancarboxaldehyde, Methyl } \\
\text { furancarboxylate, 2-Hydoxy benzaldehyde, 4-Methyl phenol, and 2-Methoxy phenol [1] }\end{array}$ & GC-MS \\
\hline & Clinical samples: Absence of hydrocarbons and terpenes besides presence of phenols and indoles [1] & \\
\hline C. jejuni & $\begin{array}{l}\text { Six significant discriminator VOCs between C. jejuni positive and negative fecal samples: Hexanal, (E)-2-Octenal, } \\
\text { Pyrrole, Ethyl ethanoate, Methyl alcohol, 2-Heptanone [19] }\end{array}$ & GC-MS \\
\hline H. pylori & $\begin{array}{l}\text { Propane, Acetaldehyde, Ethanol, Methanethiol, 1-Butene, 2-Butene, Isobutane, 2-Methyl-1-propene, Acetonitrile, } \\
\text { Butane, Pentafluoroethane, Acetone, Carbon disulfide, 2-Propanol, Ethylether, Methyl acetate, } \\
\text { Dichlorofluoroethane, 2-Methylbutane, 2-Pentene, Pentane, Cyclopentane, 2-Methylpropanal, Trichloromethane, 2- } \\
\text { Butanone, 4-Methylpentane, 1-Pentano, Ethylcyclopropane, Dimethyl disulfide, 2-Ethoxy-2-methylpropane, 3- } \\
\text { Methylbutanal, Mercaptoacetone, Toluene, Cyclohexane, Hexane, Methylcyclopentane, Benzene, 3-Methylpentane, } \\
\text { 2-Methylpentane, 2-Methyl-1-propanol, 2-Methyl-1-pentene, Ethyl acetate, Methylcyclohexane, Tetrahydro-2,2,4,4- } \\
\text { tetramethylfuran, Ethylbenzene, Styrene, 2,4-Dimethyl-1-heptene, Octane, 3,5-Dimethyloctane, 3-Ethyloctane, } \\
\text { Decane [20,21] }\end{array}$ & GC-MS \\
\hline
\end{tabular}

Table 1: Summarize of the reviewed studies on VOCs profile for different pathogens in this review paper

\section{Pathogens in cystic fibrosis patients and VOCs}

$P$. aeruginosa is a well-studied bacterium in terms of the bacterial in vitro VOCs profile in the last four decades [10,13,15,16,24-26]. This bacterium, which has been known as the main cause of cross lung infection in $85.6 \%$ of cystic fibrosis patients, can decrease lung function resulting in high patient morbidity and mortality [27-30]. A wide variety of VOCs such as ethanol, acetone, 2-butanone, 2pentanone, isoprene, aminoacetophenone, dimethyl sulphide, dimethyl disulphide, dimethyl trisulphide, methyl thiocyanate, 3methyl-butanone, acetophenone, methylthioacetate and methyl thiobutanoate have been identified as metabolites of $P$. aeruginosa [13]. A landmark study which analyzed the VOCs profile of $11 P$. aeruginosa strains demonstrated that all 11 strains could produce typical methyl ketones, particularly 2-nonanone, 2-undecanone and 2aminoacetophenone in the headspace of bacterial culture [15]. Production of 1-undecene and the lack of oxygenated compounds production in the headspace of Pseudomonas bacterial culture could be used to differentiate between this bacterium from Serratia liquefaciens and Enterobacter cloachae [31].

The VOCs profile of five bacterial species including P. aeruginosa, Staphylococcus aureus, E. coli, Salmonella enterica serovar typhimurium and Salmonella enterica serovar pullorum were compared to assess the ability of their VOCs profiles to differentiate between those bacteria. The first three principal component analysis of VOCs profiles of the mentioned bacteria demonstrated a clear discriminant use of the bacterium's VOCs patterns for identification [14]. VOCs analysis of $S$. aureus and $P$. aeruginosa in a mixed culture showed the linear correlation between detected VOCs patterns of those two bacteria with their proportion in the culture media. Changing from $\mathrm{S}$. aureus's VOCs profile to $\mathrm{P}$. aeruginosa's VOCs profile was observed when there was a decrease in the proportion of $S$. aureus in mixed bacterial culture containing those two bacteria [14].

There were approximately $25 \%-35 \%$ common VOCs between in vivo (exhaled breath samples of infected mice) and in vitro experiments of individual $P$. aeruginosa $\mathrm{PAO} 1, P$. aeruginosa FRD1 
and $S$. aureus RN450 [32]. The results of this experiment not only demonstrated the capability of differentiation between infected mice from uninfected mice, but could also be used to differentiate between mice infected by $S$. aureus and P. aeruginosa. Furthermore, it was found that the mice that had been infected by $P$. aeruginosa strains PAO1 and FRD1 could be distinguished from each other by using identified VOCs [32]. Hydrogen cyanide ( $\mathrm{HCN})$, which has been identified as a significant marker in the exhaled breath samples of cystic fibrosis (CF) patients, could be used as a marker for $P$. aeruginosa detection with $68 \%$ sensitivity and $100 \%$ specificity $[13,16,33]$. Additionally, the exhaled breath VOCs profile of CF patients with and without $P$. aeruginosa could be differentiated based on C5-C16 hydrocarbons and N-methyl-2-methylpropylamine [34].

2-nonanone was another volatile compound that could be used as a marker of $P$. aeruginosa detection in the headspace of bronchiectasis and cystic fibrosis septum samples with $72 \%$ sensitivity and $88 \%$ specificity [17]. However, this sensitivity increased by $19 \%$ for 2 nonanone in combination with 17 other detected compounds. Methyl thiocyanate was also another marker with the concentration of 2-21 ppbv in the exhaled breath of CF patients infected by $P$. aeruginosa as well as in the headspace of $P$. aeruginosa bacterial culture [30]. Interestingly, finding the parallel correlation of hydrogen cyanide concentration with methyl thiocyanate has revealed that hydrogen cyanide production is required for methyl thiocyanate production by 36 strains of this bacterium in the headspace of bacterial culture [30]. Therefore, taken together the results from the mentioned studies $P$. aeruginosa VOCs profile can be a sensitive and specific biomarkers for its identification and detection in human specimen's samples as well as in pure and mixed bacterial culture.

\section{Pulmonary pathogens and their VOCs profiles}

Analysis of pulmonary pathogen's VOCs showed significant value in developing a fast and precise detection of pulmonary infection. The headspace VOCs profiles of potential pulmonary infectious microorganisms which include E. coli, P. aeruginosa, $S$. aureus and Klebsiella pneumonia could be used to discriminate between bacterial cultures and culture medium. Furthermore, statistical discriminant analysis of VOCs patterns for the assessed microorganisms has proved the use of 25 VOCs to distinguish between different bacterial cultures from each other [35].

Mycobacterium avium subsp. paratuberculosis (MAP) is a leading cause of Johne's disease (paratuberculosis) [18]. Five different MAP strains including strains DSM 44133, JIII-386, JII-2421, JII-3197 and JII-0817 could be distinguished from blank culture media by using their VOCs profiles. 34 VOCs out of 100 substances were selected as significant VOCs from all cultured bacterial strains. However, the relative abundances of those 34 compounds were significantly different between all five strains. In addition, furan compounds such as furan, 2-pentylfuran, 2-methylfuran and 3-methylfuran showed the highest concentration in the headspace of MAP bacterial culture in comparison with aldehydes, hydrocarbons and nitrogen and sulfur containing compounds [18].

Electronic-nose system that is made of multisensory array has been considered in biomedical studies as a portable device for VOCs detection from human samples such as exhaled breath and fecal sample [36-40]. This device also has been used to define the in vitro VOCs profile of Mycobacterium tuberculosis and by using this profile researchers could differentiate this bacterium from four other bacterial species including $M$. tuberculosis, M. avium, M. scrofulaceum and $P$. aeruginosa [41]. In addition, the results of in situ studies of tuberculosis (TB) patient's septum showed the ability of using an electronic nose to identify tuberculosis infections between healthy samples and those with $M$. avium and $P$. aeruginosa infections [41].

Another gas sensing system based on 14 conducting polymers also used for examination of 196 septum samples including $134 \mathrm{M}$. tuberculosis positive culture samples and 79 M. tuberculosis negative culture samples. The result of this study showed an $89 \%$ sensitivity and 91\% specificity for $M$. tuberculosis diagnosis from $M$. tuberculosis, $M$. avium, $M$. scrofulaceum and $P$. aeruginosa infections [42]. The results of these two experiments revealed that 14 sensors conducting polymer array were able to screen TB patients from healthy subjects and other bacterial infections with a reasonable sensitivity and specificity $[41,42]$.

\section{Food-borne pathogens and their VOCs profiles}

Finding the VOCs biomarkers for the identification of bacteria that cause diarrhea was one of the first studies of using fecal VOCs analysis. The study found a furan producing species without indole production correlated to the VOC profile of Clostridium difficile in the fecal samples of infectious diarrhea patients. In addition, the absence of hydrocarbons and terpenes in fecal samples indicated the presence of a Campylobacter jejuni infection in diarrheal sample from the patient [1].

E. coli $\mathrm{O} 157: \mathrm{H} 7$ has been known as a main cause of acute hemorrhagic diarrhea and abdominal cramps. This bacterium has been identified as a human infection microorganism in 1982 in two hemorrhagic colitis patients and after that it was entered to the clinical research area for the public health concern $[43,44]$. Human infections by this strain is appeared by symptom free carriage, non-bloody diarrhoea, haemorrhagic colitis, haemolytic uraemic syndrome and death [43].

VOC analysis was used to distinguish between E. coli O157:H7, S. aureus and $S$. typhimurium in bacterial culture media. Six core peaks were detected as a signature for $E$. coli detection. The identified signature could be used to differentiate this bacterium from $S$. aureus and $S$. typhimurium. These six peaks were assigned for eleven different strains of $E$. coli and it was observed that detected peaks were presented in all eleven strains and could be used as biomarkers to detect this bacterium. Furthermore, E. coli $\mathrm{O} 157: \mathrm{H} 7$ and $\mathrm{O} 145$ could be differentiated from other nine E. coli strains by using their VOCs profiles [45]. In another experiment, the VOCs profile of $S$. aureus showed significant differences from E. coli and Klebsiella pneuminiae VOCs in terms of lacking 1-decanol and 1-dodecanol in E. coli and $\mathrm{K}$. pneuminiae within bacterial culture media [46].

Campylobacter jejuni is a major prevalent food-borne pathogen that causes gastroenteritis worldwide [47,48]. VOCs analysis of this bacterium showed significant commonness of 2-hexanone, (E)-3hexen-2-one, hexanal, (E)-2-octenal and pyrrole in Campylobacter positive fecal samples of chickens [19]. In addition, the authors reported a significant differences in the abundance of hexanal, (E)-2octenal, pyrrole, ethyl ethanoate, methyl alcohol and 2-heptanone between two groups of Campylobacter positive and negative chicken fecal samples which can be used for biomarkers with $96 \%$ and $95 \%$ sensitivity and specificity, respectively [19]. 


\section{Gastrointestinal pathogens and their VOCs profiles}

After isolation and identification of Helicobacter pylori from patient's gastric mucosa in 1983, this bacterium has been known as a major cause of gastric disorders such as chronic active gastritis and peptic ulcer disease $[49,50]$. Isobutane, 2-butanone and ethyl acetate were observed in breath samples of $\mathrm{H}$. pylori positive subjects as well as in the headspace of $\mathrm{H}$. pylori bacterial culture media while these compounds were not detected in exhaled breath of $\mathrm{H}$. pylori negative subjects [20]. Another example of gut microbiome related VOCs is the changing the level of ethanol in the exhaled breath of obese mice that have been changed in the composition of their intestinal microflora [51].

VOCs profile analysis of $\mathrm{H}$. pylori in the bacterial culture media and the analysis of VOCs emitted from stomach cancer tissues showed overlapping of 8 VOCs between cultured $\mathrm{H}$. pylori and the VOCs of cancer tissues. In addition, carbon disulfide, 1-propanol, 2-propanol, 2-butanone, 4-methylheptane, 4-methyloctane and 2-ethyl-1-hexanol were recognized as cancer biomarkers in that study [21]. Detection of carbon disulfide and1-propanol as common detected VOCs in bacterial culture media and the emitted VOCs from cancerous tissues suggested that increasing in the concentration of emitted these VOCs from cancerous tissue might be as a results of presence of $\mathrm{H}$. pylori in conjugation with cancerous tissue [21].

Recent gut microbiome studies have revealed the significant roles of gastrointestinal microbiota in promoting both health and disease in humans including gastrointestinal disorders, chronic systemic metabolic and inflammatory diseases [52]. One of the potential function of intestinal microbiota to promote health or disease is their important metabolic functions such as fermentation, vitamin synthesis and energy storage via short chain fatty acids production $[53,54]$.

Fecal metabolites profiling along with fecal microbiota profile analysis have been employed to find the valuable markers for diagnosis of some non-infectious disorders such as autism, colorectal cancer, chronic gastrointestinal disease, celiac disease, nonalcoholic fatty liver disease and necrotising enterocolitis [55-60]. For example, there was a notable positive correlation between the presence of Phascolarctobacterium and Acidiminobacter with concentration of phenylalanine and glutamate. Furthermore, the modest correlation with concentration of serine and threonine in fecal samples of colorectal cancer patients was observed in that study [59]. High concentration of ester, indole and alcohol derivates of short-chain fatty acids in Crohn's disease patient's fecal samples in comparison with the concentration of mentioned VOCs of healthy volunteers, ulcerative colitis, and ulcerative colitis fecal samples is another example of significant value of fecal VOCs in bacterial related diseases diagnosis [60]. Therefore, the results of fecal microbiota analysis and their VOCs profile promote the idea of using qualitative and quantitative analysis of fecal metabolites to evaluate fecal bacterial communication. The generated data from this kind of analysis can be used for developing a fast and sensitive diagnostic method.

\section{Conclusion}

VOCs have been extensively studied in recent years because of their aptitude to be used in bacterial identification and differentiation. The qualitative and quantitative characteristics of microbial VOCs pattern allow researchers to identify bacterial VOCs as sensitive and specific biomarkers for rapid bacterial detection even though more research need to be done to improve biomarkers discovery. The application of bacterial VOCs for developing none-invasive and rapid in situ bacterial detection methods would have enormous promises in clinical diagnosis of infections and real time monitoring of disease development as well as the effect of treatment.

\section{Acknowledgement}

MS is support by Postgraduate Research Scholarship and International Postgraduate Research Scholarship, Griffith University, Australia.

\section{References}

1. Probert C, Jones P, Ratcliffe N (2004) A novel method for rapidly diagnosing the causes of diarrhoea. GUT 53:58-61.

2. Li Y, Wu S, Wang L, Li Y, Shi F, et al. (2010) Differentiation of bacteria using fatty acid profiles from gas chromatography-tandem mass spectrometry. J Sci Food Agric 90: 1380-1383.

3. Ehrhardt CJ, Chu V, Brown T, Simmons TL, Swan BK, et al. (2010) Use of fatty acid methyl ester profiles for discrimination of Bacillus cereus $\mathrm{T}$ strain spores grown on different media. Applied and Environmental Microbiology 76:1902-1912.

4. Roberts LD, Souza AL, Gerszten RE, Clish CB (2001) Targeted Metabolomics, Current Protocols in Molecular Biology. John Wiley \& Sons, Inc.

5. Glish GL, Vachet RW (2003) The basics of mass spectrometry in the twenty-first century. Nature Reviews Drug Discovery 2:140-150.

6. Dixon E, Clubb C, Pittman S, Ammann L, Rasheed Z, et al. (2011) Solidphase microextraction and the human fecal VOC metabolome. PLoS ONE 6:e18471.

7. Pagans E, Font X, Sánchez A (2006) Emission of volatile organic compounds from composting of different solid wastes: Abatement by biofiltration. Journal of hazardous materials 131:179-186.

8. GELDREICH EE, KENNER BA, KABLER PW (1964) OCCURRENCE OF COLIFORMS, FECAL COLIFORMS, AND STREPTOCOCCI ON VEGETATION AND INSECTS. Appl Microbiol 12: 63-69.

9. Wang D, Ding X, Rather PN (2001) Indole Can Act as an Extracellular Signal inEscherichia coli. Journal of Bacteriology 183:4210-4216.

10. Cox CD, Parker J (1979) Use of 2-aminoacetophenone production in identification of Pseudomonas aeruginosa. J Clin Microbiol 9: 479-484.

11. Bos LD, Sterk PJ, Schultz MJ (2013) Volatile metabolites of pathogens: a systematic review. PLoS Pathog 9: e1003311.

12. Schulz S, Dickschat JS (2007) Bacterial volatiles: the smell of small organisms. Nat Prod Rep 24: 814-842.

13. Shestivska V, Španel P, Dryahina K, Sovová K, Smith D, et al. (2012) Variability in the concentrations of volatile metabolites emitted by genotypically different strains of Pseudomonas aeruginosa. Journal of Applied Microbiology 113:701-713.

14. Zhu J, Bean HD, Kuo YM, Hill JE (2010) Fast detection of volatile organic compounds from bacterial cultures by secondary electrospray ionization-mass spectrometry. J Clin Microbiol 48: 4426-4431.

15. Labows JN, McGINLEY KJ, Webster G, Leyden J (1980) Headspace analysis of volatile metabolites of Pseudomonas aeruginosa and related species by gas chromatography-mass spectrometry. Journal of Clinical Microbiology 12:521-526.

16. Carroll W, Lenney W, Wang T, Španel P, Alcock A, et al. (2005) Detection of volatile compounds emitted by Pseudomonas aeruginosa using selected ion flow tube mass spectrometry. Pediatric Pulmonology 39:452-456.

17. Savelev SU, Perry JD, Bourke SJ, Jary H, Taylor R, et al. (2011) Volatile biomarkers of Pseudomonas aeruginosa in cystic fibrosis and noncystic fibrosis bronchiectasis. Lett Appl Microbiol 52: 610-613.

18. Trefz P, Koehler H, Klepik K, Moebius P, Reinhold P, et al. (2013) Volatile emissions from Mycobacterium avium subsp. paratuberculosis 
mirror bacterial growth and enable distinction of different strains. PLoS One 8: e76868.

19. Garner CE, Smith S, Elviss NC, Humphrey TJ, White P, et al. (2008) Identification of Campylobacter infection in chickens from volatile faecal emissions. Biomarkers 13: 413-421.

20. Ulanowska A, Kowalkowski T, Hrynkiewicz K, Jackowski M, Buszewski B (2011) Determination of volatile organic compounds in human breath for Helicobacter pylori detection by SPME-GC/MS. Biomed Chromatogr 25: 391-397.

21. Buszewski B, Ulanowska A, Ligor T, Jackowski M, Klodzinska E, et al. (2008) Identification of volatile organic compounds secreted from cancer tissues and bacterial cultures. Journal of Chromatography B: Biomedical Sciences and Applications 868:88-94.

22. Thorn RMS, Greenman J (2012) Microbial volatile compounds in health and disease conditions. Journal of Breath Research 6:024001.

23. Chen W, Liu F, Ling Z, Tong X, Xiang C (2012) Human intestinal lumen and mucosa-associated microbiota in patients with colorectal cancer. PLoS ONE 7:e39743.

24. Kunze N, Göpel J, Kuhns M, Jünger M, Quintel M, et al. (2013) Detection and validation of volatile metabolic patterns over different strains of two human pathogenic bacteria during their growth in a complex medium using multi-capillary column-ion mobility spectrometry (MCC-IMS). Applied microbiology and biotechnology 97: 3665-3676.

25. Filipiak W, Sponring A, Baur MM, Filipiak A, Ager C, et al. (2012) Molecular analysis of volatile metabolites released specifically by Staphylococcus aureus and Pseudomonas aeruginosa. BMC Microbiol 12:113.

26. Zechman JM, Aldinger S, Labows Jr JN (1986) Characterization of pathogenic bacteria by automated headspace concentration-gas chromatography. Journal of Chromatography B: Biomedical Sciences and Applications 377: 49-57.

27. Laraya-Cuasay LR, Cundy KR, Huang NN (1976) Pseudomonas carrier rates of patients with cystic fibrosis and of members of their families. The Journal of pediatrics 89:23-26.

28. Davies JC (2002) Pseudomonas aeruginosa in cystic fibrosis: pathogenesis and persistence. Paediatr Respir Rev 3: 128-134

29. Ratjen F (2006) Treatment of early Pseudomonas aeruginosa infection in patients with cystic fibrosis. Current opinion in pulmonary medicine 12:428-432.

30. Shestivska V, Nemec A, Drevínek P, Sovová K, Dryahina K, et al. (2011) Quantification of methyl thiocyanate in the headspace of Pseudomonas aeruginosa cultures and in the breath of cystic fibrosis patients by selected ion flow tube mass spectrometry. Rapid Communications in Mass Spectrometry 25:2459-2467.

31. Schöller C, Molin S, Wilkins K (1997) Volatile metabolites from some gram-negative bacteria. Chemosphere 35: 1487-1495.

32. Zhu J, Bean HD, Wargo MJ, Leclair LW, Hill JE (2013) Detecting bacterial lung infections: in vivo evaluation of in vitro volatile fingerprints. J Breath Res 7:1752-7155.

33. Enderby B, Smith D, Carroll W, Lenney W (2009) Hydrogen cyanide as a biomarker for Pseudomonas aeruginosa in the breath of children with cystic fibrosis. Pediatr Pulmonol 44: 142-147.

34. Robroeks CM, van Berkel JJ, Dallinga JW, Jöbsis Q, Zimmermann LJ, et al. (2010) Metabolomics of volatile organic compounds in cystic fibrosis patients and controls. Pediatr Res 68: 75-80.

35. Boots AW, Smolinska A, van Berkel JJ, Fijten RR, Stobberingh EE, et al. (2014) Identification of microorganisms based on headspace analysis of volatile organic compounds by gas chromatography-mass spectrometry. J Breath Res 8: 027106.

36. De Meij TG, Larbi IB, van der Schee MP, Lentferink YE, Paff T, et al. (2013) Electronic nose can discriminate colorectal carcinoma and advanced adenomas by fecal volatile biomarker analysis: proof of principle study. International Journal of Cancer: 1132-1138.
37. Peng G, Tisch U, Adams O, Hakim M, Shehada N, et al. (2009) Diagnosing lung cancer in exhaled breath using gold nanoparticles. Nat Nanotechnol 4: 669-673.

38. Peng G, Hakim M, Broza YY, Billan S, Abdah-Bortnyak R, et al. (2010) Detection of lung, breast, colorectal, and prostate cancers from exhaled breath using a single array of nanosensors. Br J Cancer 103: 542-551.

39. Hakim M, Billan S, Tisch U, Peng G, Dvrokind I, et al. (2011) Diagnosis of head-and-neck cancer from exhaled breath. British journal of cancer 104:1649-1655.

40. Wilson AD, Baietto M (2009) Applications and advances in electronicnose technologies. Sensors (Basel) 9: 5099-5148.

41. Pavlou AK, Magan N, Jones JM, Brown J, Klatser P, et al. (2004) Detection of Mycobacterium tuberculosis (TB) in vitro and in situ using an electronic nose in combination with a neural network system. Biosens Bioelectron 20: 538-544.

42. Fend R, Kolk AH, Bessant C, Buijtels P, Klatser PR, et al. (2006) Prospects for clinical application of electronic-nose technology to early detection of Mycobacterium tuberculosis in culture and sputum. J Clin Microbiol 44: 2039-2045.

43. Mead PS, Griffin PM (1998) Escherichia coli O157:H7. The Lancet 352:1207-1212.

44. Riley LW, Remis RS, Helgerson SD, McGee HB, Wells JG, et al. (1983) Hemorrhagic colitis associated with a rare Escherichia coli serotype. $\mathrm{N}$ Engl J Med 308: 681-685.

45. Zhu J, Hill JE (2013) Detection of Escherichia coli via VOC profiling using secondary electrospray ionization-mass spectrometry (SESI-MS). Food Microbiol 34: 412-417.

46. Tait E, Perry JD, Stanforth SP, Dean JR (2013) Identification of Volatile Organic Compounds Produced by Bacteria Using HS-SPME-GC-MS. J Chromatogr Sci.

47. Allos BM (2001) Campylobacter jejuni Infections: update on emerging issues and trends. Clin Infect Dis 32: 1201-1206.

48. Murphy C, Carroll C, Jordan KN (2006) Environmental survival mechanisms of the foodborne pathogen Campylobacter jejuni. J Appl Microbiol 100: 623-632.

49. Robin Warren J, Marshall B (1983) UNIDENTIFIED CURVED BACILLI ON GASTRIC EPITHELIUM IN ACTIVE CHRONIC GASTRITIS. The Lancet 321:1273-1275.

50. Pakodi F, Abdel-Salam OM, Debreceni A, Mózsik G (2000) Helicobacter pylori. One bacterium and a broad spectrum of human disease! An overview. J Physiol Paris 94: 139-152.

51. Cope K, Risby T, Diehl AM (2000) Increased gastrointestinal ethanol production in obese mice: Implications for fatty liver disease pathogenesis. Gastroenterology 119:1340-1347.

52. Tremaroli V, Bäckhed F (2012) Functional interactions between the gut microbiota and host metabolism. Nature 489: 242-249.

53. Couch RD, Navarro K, Sikaroodi M, Gillevet P, Forsyth CB, et al. (2013) The approach to sample acquisition and its impact on the derived human fecal microbiome and VOC metabolome. PLoS One 8: e81163.

54. Sharma R, Young C, Neu J (2010) Molecular modulation of intestinal epithelial barrier: contribution of microbiota. J Biomed Biotechnol 2010: 305879.

55. De Angelis M, Piccolo M, Vannini L, Siragusa S, De Giacomo A, et al. (2013) Fecal microbiota and metabolome of children with autism and pervasive developmental disorder not otherwise specified. PLoS One 8: e76993.

56. Di Cagno R, De Angelis M, De Pasquale I, Ndagijimana M, Vernocchi $\mathrm{P}$, et al. (2011) Duodenal and faecal microbiota of celiac children: molecular, phenotype and metabolome characterization. BMC Microbiol 11: 219 .

57. Garner CE, Ewer AK, Elasouad K, Power F, Greenwood R, et al. (2009) Analysis of faecal volatile organic compounds in preterm infants who develop necrotising enterocolitis: a pilot study. Journal of pediatric gastroenterology and nutrition 49:559-565. 
Citation: Sohrabi M, Zhang L, Zhang K, Ahmetagic A, Wei MQ (2014) Volatile Organic Compounds as Novel Markers for the Detection of Bacterial Infections. Clin Microbial 3: 151. doi:10.4172/2327-5073.1000151

Page 6 of 6

58. Raman M, Ahmed I, Gillevet PM, Probert CS, Ratcliffe NM, et al. (2013) Fecal Microbiome and Volatile Organic Compound Metabolome in Obese Humans With Nonalcoholic Fatty Liver Disease. Clinical Gastroenterology and Hepatology 11:868-875.e863.

59. Weir TL, Manter DK, Sheflin AM, Barnett BA, Heuberger AL, et al. (2013) Stool microbiome and metabolome differences between colorectal cancer patients and healthy adults. PLoS ONE 8:e70803.
60. Walton C, Fowler DP, Turner C, Jia W, Whitehead RN, et al. (2013) Analysis of volatile organic compounds of bacterial origin in chronic gastrointestinal diseases. Inflamm Bowel Dis 19:2069-2078. 